\title{
Effect of salt stress on the activity of bromelain in pineapple plants grown In vitro
}

\author{
Jaci Vilanova-Neta', Diego Menezes ${ }^{1}$, Márcio Barreto ${ }^{1}$, Jaqueline Souza ${ }^{1 *}$, Antônio Carvalho-Neto ${ }^{1}$, Ana Lédo ${ }^{2}$, \\ Denise Ruzene ${ }^{1}$, Daniel Silva ${ }^{3}$ \\ From 5th Congress of the Brazilian Biotechnology Society (SBBIOTEC) \\ Florianópolis, Brazil. 10-14 November 2013
}

\section{Background}

Bromelain is a collective name for proteolytic enzymes or proteases (natural proteolytic enzymatic complex) found in tissues including stems, fruit and leaves of the pineapple (Ananas comosus var. comosus) and of other plant species of the family Bromeliaceae [1]. Is a bioactive agent possessing remarkable therapeutic properties such as reversible inhibition of platelet aggregation, relief from bronchitis, sinusitis and enhanced absorption of drugs, particularly of antibiotics [2]. Although Brazil is a major producer of pineapple, occupying the first position in 2010 worldwide with a production of 1.5 million tons of fruit, the salt stress, deleterious alterations observed in plants grown in saline conditions, which occur due to intoxication by ions and decline of supply of water and nutrients to the plant [3] is main factor limiting growth and productivity of plants since it causes metabolic responses in plants, affecting and compromising all important processes such as photosynthesis, changes in levels and protein synthesis and activity enzymes, as well as in the synthesis of lipid metabolism and energy [4]. Thus, the objective of this research was to evaluate the influence of salt stress on the activity of bromelain in pineapple plants (Ananas comosus L. Merril) cv. Pérola cultured in vitro.

\section{Methods}

The bromelain activity was avaliable from crude extracts of leaves and stems from plants of pineapple, Ananas comosus var. comosus, cv. Pérola, cultivated in vitro in culture medium MS [5] with growth regulator, BAP (6-benzilaminopurina) and ANA (ácido naftalenoacético) in fixed concentrations and sodium chloride at different concentrations, constituting thus, different tretaments.

Universidade Tiradentes, Instituto de Tecnologia e Pesquisa, Aracaju, SE, Brasil

Full list of author information is available at the end of the article
The enzyme was obtained from crude extracts of leaves and stems from plants of pineapple in vitro, after mixture in $2.5 \mathrm{ml}$ of $0.2 \mathrm{M}$ phosphate buffer at $\mathrm{pH} 5.7$ and filtering twice through cheesecloth. Total protein concentration was determined by the Bradford method using Coomassie Blue G250 and the proteolytic activity of the bromelain enzyme was determined based on the method described earlier [6,7]. A Bovine Serum Albumin was used as a substrate to be hydrolysed by the enzyme bromelain.

\section{Results and conclusion}

According to the results, the bromelain activity, total protein concentration and specific activity obtained in pineapple plants cv. Pérola showed variation in relation to salinity levels and plant tissue analysis (stem or leaf). In quantitative terms, the more significant levels of proteoltic activity of bromelain were obtained in tissues from pineapple stems of the treatment corresponding to a concentration of $100 \mathrm{mM} \mathrm{NaCl}$. Our findings corroborate results obtained in other vegetables and can be used in optimizing crop when in coastal regions or in saline soils.

Acknowledgements

The authors thank the EMBRAPA, FAPITEC/SE and CAPES.

\section{Authors' details}

'Universidade Tiradentes, Instituto de Tecnologia e Pesquisa, Aracaju, SE, Brasil. ${ }^{2}$ Embrapa Tabuleiros Costeiros, Aracaju, SE, Brasil. ${ }^{3}$ Universidade Federal de Sergipe, Núcleo de Engenharia de Produção, São Cristovão, SE, Brasil.

Published: 1 October 2014

\section{References}

1. Bhui KPS, George J, Shukla Y: Bromelain inhibits COX-2 expression by blocking the activation of MAPK regulated NF-kappa B against skin tumor-initiation triggering mitochondrial death pathway. Cancer Letters 2009, 282:167-176 
2. Kumar S, Hemavathi AB, Hebbar HU: Affinity based reverse micellar extraction and purification of bromelain from pineapple (Ananas comosus L. Merryl) waste. Process Biochemistry 2011, 46:1216-1220.

3. Li Y, Zhang Y, Feng F, Liang D, Cheng L, Ma F, Shi S: Overexpression of a Malus vacuolar $\mathrm{Na}+/ \mathrm{H}+$ antiporter gene $(\mathrm{MdNHX} 1)$ in apple rootstock M.26 and its influence on salt tolerance. Plant Cell Tissue Organ Cult 2010, 102:337-345.

4. Piza IMT, Lima GPP, Brasil OG: Atividade de peroxidase e níveis de proteínas em plantas de abacaxizeiro micropropagadas em meio salino. Revista Brasileira de Agrociência 2003, 9(4):361-366.

5. Murashige T, Skoog F: A revised medium for rapid growth and bioassays with tobacco tissue cultures. Physiologia Plantarum 1962, 15:473-497.

6. Murachi T: Bromelain enzyme. In Methods in Enzymology L. Lorand. New York, USA:; Academic Press; 1976, 45:475-585, 1976

7. Baldini VLS, laderoza M, Ferreira EAH, Sales AM, Draetta IS, Giacomelli EJ: Ocorrência da bromelina e cultivares de abacaxizeiro. Coletânea do ITAL 1993, 23(1):44-55.

doi:10.1186/1753-6561-8-S4-P199

Cite this article as: Vilanova-Neta et al.: Effect of salt stress on the activity of bromelain in pineapple plants grown In vitro. BMC Proceedings 2014 8(Suppl 4):P199.

\section{Submit your next manuscript to BioMed Central and take full advantage of:}

- Convenient online submission

- Thorough peer review

- No space constraints or color figure charges

- Immediate publication on acceptance

- Inclusion in PubMed, CAS, Scopus and Google Scholar

- Research which is freely available for redistribution

Submit your manuscript at www.biomedcentral.com/submit 